проблеми теорії та практики. - 2014. Випуск № 119. - С. 43-48.

7.Сорокин Г.М. Экономическая эффективность при социализме. - М.: Наука, 1979. - 335 c.
8.Сінгаєвська М.П. Економічна ефективність на підприємствах залізничного транспорту / Проблеми інформатизації та управління. - 2015. - № 13. - C. $41-51$

УДК 658:656.2(477)

\title{
СТРАТЕГІЧНИЙ МЕНЕДЖМЕНТ ТА ЙОГО ВИКОРИСТАННЯ В ПРАКТИЦІ ФОРМУВАННЯ І ДОСЯГНЕННЯ ЦІЛЕЙ РОЗВИТКУ ЗАЛІЗНИЧНОГО ТРАНСПОРТУ
}

\author{
Дикань О. В., д.е.н., професор, \\ Смаль О.В., магістрант програми ТЕМПУС (УкрДУЗТ)
}

\begin{abstract}
В статі встановлено, щуо на сьогодні в залізничній галузі максимально загострюється актуальність питання залучення нових стратегічних підходів та методів до галузевих економічних прочесів. Від іх розвитку залежать результати роботи підприємств, тому проблеми розвитку методів стратегічного менеджменту та іх використання в практиці формування $i$ досягнення цілей залізничного транспорту є актуальними.

Для визначення особливостей використання стратегічного менеджменту в статті управління залізничним транспортом досліджено існуючий теоретичний базис з окресленої тематики. Встановлено, щуо існуюча стратегія розвитку залізничного транспорту має тактичне спрямування, а не стратегічне. Визначені напрямки та передумови удосконалення теоретичного базису стратегічного менеджменту на залізничному транспорті Украӥни.
\end{abstract}

Ключові слова: стратегічний менеджмент, ринкова економіка, стратегічний аналіз, управління, залізничний транспорт.

\section{СТРАТЕГИЧЕСКИЙ МЕНЕДЖМЕНТ И ЕГО ИСПОЛЬЗОВАНИЕ В ПРАКТИКЕ ФОРМИРОВАНИЯ И ДОСТИЖЕНИЯ ЦЕЛЕЙ РАЗВИТИЯ ЖЕЛЕЗНОДОРОЖНОГО ТРАНСПОРТА}

\author{
Дикань Е.В. д.э.н., профессор, \\ Смаль А.В., магистрант программы ТЕМПУС (УкрГУЖТ)
}

В статье установлено, что сегодня в железнодорожной отрасли максимально обостряется актуальность вопроса привлечения новых стратегических подходов и методов в отраслевых экономических процессах. От их развития зависят результаты работь предприятий, поэтому проблемь развития методов стратегического менеджмента и их использование в практике формирования и достижения иелей железнодорожного транспорта являются актуальными.

(C) Дикань O.B.,

Смаль О.В.
Вісник економіки транспорту і промисловості № 59, 2017 
Для определения особенностей использования стратегического менеджмента в статье управление железнодорожным транспортом исследован существующий теоретический базис по обозначенной тематике. Установлено, что существуюшая стратегия развития железнодорожного транспорта имеет тактическое направление, а не стратегическое. Определены направления и предпосылки усовершенствования теоретического базиса стратегического менеджмента на железнодорожном транспорте Украины.

Ключевые слова: стратегический менеджмент, рыночная экономика, стратегический анализ, управление, железнодорожный транспорт.

\title{
STRATEGIC MANAGEMENT AND ITS USE IN THE PRACTICE OF FORMING AND ACHIEVING GOALS OF DEVELOPMENT OF RAILWAY TRANSPORT
}

\author{
Dykan O.V., Doctor of Economics, Professor, \\ Smal A., Master of program TEMPUS (USU RT)
}

The article shows that today in the railway industry intensify to the utmost the importance of bringing in new strategic approaches and techniques in the industry of economic processes. Their development depends on the results of work of the enterprises, so the problem of development of methods of strategic management and their use in the practice of the formation and the achievement of the objectives of rail transport are relevant.

To determine the usage of strategic management in the article the management of rail investigated the existing theoretical basis for the designated category. It is established that the current strategy of development of railway transport has tactical direction, and not strategic. Directions and preconditions of improvement of the theoretical basis of strategic management in railway transport of Ukraine.

Keywords: strategic management, market economy, strategic analysis, management, railway transport.

Постановка проблеми. На сьогодні в економіці України забезпечення ефективної діяльності залізничного транспорту потребує його адаптації до умов ринкового господарювання, що забезпечує важливу роль впровадження стратегічного менеджменту на підприємствах галузі, а саме: розробка та реалізація науково обгрунтованих стратегій розвитку як підприємств, так і галузі в цілому, зокрема, ключове значення має використання методів стратегічного менеджменту. Від їх розвитку залежать результати роботи залізничного транспорту, тому проблеми розвитку методів стратегічного менеджменту та його використання в практиці формування і досягнення цілей галузі є актуальною.

Аналіз останніх досліджень i публікацій. Питання оцінки стратегії розвитку, в контексті теорії організації стратегічного менеджменту та планування, теорії менеджменту, розглядались багатьма іноземними та вітчизняними вченими, зокрема, Аванесова Н. Е. [1], Балабанова Л. В. [2], Боярко І. М. [3], Василенко Д. Ю. [4], Виханский О. С. [5], Стадник В. В. [9] та інші. Закладена вченими наукова база, полегшує пошук рішень проблеми, не зменшуючи важливості роботи в області стратегічного розвитку залізничного транспорту, оскільки в силу специфічних умов розвитку західних економік, науково

Вісник економіки транспорту і промисловості № 59, 2017 
- теоретична база не завжди може бути дзеркально використана на вітчизняному залізничному транспорті.

Метою статті $\mathbf{c}$ дослідження особливостей впровадження стратегічного менеджменту на підприємствах залізничного транспорту.

Виклад основного матеріалу. Процеси глобалізації у світовій економіці, поглиблення міжнародного поділу праці, формування сучасних організацій вимагають створення в кожній країні клімату підприємницької активності, механізмів стратегічного розвитку, ефективної ринкової інфраструктури. Сучасний етап розвитку національної економіки України характеризується пошуком найефективніших важелів та інструментів ведення виробничогосподарської діяльності на залізничному транспорті, який, як основа транспортної системи України, забезпечує життєдіяльність всіх галузей економіки. На сучасному етапі розвитку залізничного транспорту все більш актуально постає питання необхідності залучення нових стратегічних підходів та методів до галузевих економічних процесів. Конкурентна боротьба в транспортному секторі економіки, реформування залізничного транспорту обумовлюють необхідність пошуку та впровадження нових методів стратегічного менеджменту.

Підприємства, які змогли вирішити завдання виживання у конкурентному середовищі, одержали можливість та одночасно стали перед потребою формування стратегії подальшого розвитку, основною метою якого $\epsilon$ формування множини альтернатив для прийняття стратегічних рішень, які забезпечать конкурентні переваги досліджуваного об'єкта та його прибутковість в довготерміновій перспективі. Стратегія підприємства складається із запланованих дій i поправок, якщо в них $\epsilon$ потреба. Формування стратегії включає в себе розробку плану дій та їх адаптацію до нової ринкової ситуації. Поточна стратегія розробляється менеджером підприємства 3 урахуванням подій, що відбуваються як усередині, так і за межами підприємства.

Постійно відбувається пошук шляхів більш успішного здійснення стратегіï. Її реалізація починається 3 об'єднання різних рішень i дій керівництва щодо організації роботи окремих груп i кожного працівника персонально. Перегляд бюджету, зміна політики, реорганізація, вдосконалення системи заробітної плати, впровадження нових технологій у виробничий процес усе це типові дії менеджерів, які дають змогу поліпшити стратегічну роботу.

В господарській практиці України механізм стратегічного менеджменту знаходиться на етапі становлення. При цьому європейські й українські аналітики стверджують, що український ринок вступив в ту стадію, коли відсутність розробленої стратегії заважає підприємствам на кожному кроці. Сьогодні залізничному транспорту України необхідно сформувати таку стратегію розвитку підприємства, яка дозволила б підтримувати стійкі конкурентні переваги в достроковому періоді. Досвід показує, що багато хто в Україні не бачить різниці між стратегічним плануванням і стратегічним менеджментом. Їм можуть допомогти перефразовані слова Пітера Друкера: стратегічне планування - це управління за планами, а стратегічний менеджмент управління за результатами.

Правильно обрана стратегічна політика залізничного транспорту у фінансовому аспекті не тільки допоможе закріпити позиції на ринку, але й буде сприяти розвитку підприємства в цілому.

На сьогодні в залізничній галузі максимально загострюється актуальність питання залучення нових стратегічних підходів та методів до галузевих економічних процесів. Поява та стрімкий розвиток приватних конкурентних

Вісник економіки транспорту і промисловості № 59, 2017 
структур, пов'язана 3 цим конкурентна боротьба в транспортному секторі економіки, реформування залізничного транспорту вимагають термінового пошуку та впровадження нових методів стратегічного менеджменту.

Аналіз літератури свідчить, що єдине правильне тлумачення стратегічного менеджменту відсутнє. Існують різні визначення, в яких автори роблять акцент на певних аспектах $\mathrm{i}$ особливостях стратегічного менеджменту, що призводить до невизначеності його меж. Можна констатувати, що зміст означення "стратегічний" є звуженим і це зводить стратегічний менеджмент до одного 3 напрямів управлінської діяльності, можливих і доступних будьякому суб'єкту господарської діяльності.

Особливий інтерес теоретиків і практиків до поняття і змісту стратегій, а також процесів їх здійснення виник на початку 60-х рр. XX ст.

Стратегія підприємства включає в себе розробку плану дій та їх адаптацію до поточної і прогнозованої ринкової ситуації. Поточна стратегія формується 3 урахуванням подій, що відбуваються як усередині, так і за межами підприємства. Виходячи з наявності в Україні значного ринка транспортних послуг та пов'язану 3 цим підвищену привабливість через високу прибутковість залізничного транспорту для приватних структур, існує певний ризик щодо укріплення їх позицій в зазначеному сегменті послуг, протидією котрому може бути виважена, економічно приваблива політика, якість надання послуг, бездоганність виконавця. Вирішення завдання виживання у конкурентному середовищі, дозволить підприємству одержати можливість та одночасно стати перед потребою формування стратегії подальшого розвитку, основною метою якого $\epsilon$ формування множини альтернатив для прийняття стратегічних рішень, які забезпечать високі бар'єри та конкурентні переваги досліджуваного об'єкта та його прибутковість.

Реалізація стратегії починається 3 об'єднання різних рішень i дій керівництва щодо організації роботи окремих груп i кожного працівника персонально. Перегляд бюджету, зміна політики, реорганізація, вдосконалення системи заробітної плати, впровадження нових технологій у виробничий процес усе це типові дії, які дають змогу поліпшити стратегічну роботу.

Зробити стратегічний вибір за даними стратегічного аналізу — означає пов'язати бізнес-рішення 3 конкурентоспроможними діями, виходячи при цьому 3 даних щодо всього підприємства. В цій єдності дій та підходів і полягає поточна стратегія підприємства, оскільки повний доступ до зовнішнього середовища приніс не тільки нові можливості, а й нові проблеми ефективного функціонування на ринку транспортних послуг. До необхідності впровадження стратегічних методів більшість вітчизняних підприємств та організацій інших галузей приходили i досі приходять внаслідок критичного становища зі збутом продукції або послуг. Часто керівництво помилково вважає, що воно знає своїх конкурентів, тому немає необхідності постійно відслідковувати ситуацію у галузі. Така думка призводить до того, що організація зупиняється на певному етапі розвитку, а керівництво помічає негативні зміни тільки після явного зниження обсягів реалізації та прибутків. В подібній ситуації, як правило, здійснюються спроби активізувати продажі шляхом пошуку нових ринків збуту для пропонованої продукції чи послуг, в той час як їх життєвий цикл, наприклад, внаслідок розвитку технологій у конкурентів, впровадження ними нової сировини тощо, знаходиться на стадії спаду або остаточного попиту. Звідси чітко випливає необхідність постійного моніторингу галузі і комплексного дослідження свого

Вісник економіки транспорту і промисловості № 59, 2017 
конкурентного положення в ній. Залізничний транспорт не є виключенням, ринкові позиції якого все активніше ущемляють конкуренти - автотранспорт (приміські перевезення) та авіатранспорт (дальні перевезення). Крім того, пасажирські перевезення на залізничному транспорті досі залишаються збитковими.

У зв'язку 3 цим можна виділити головну проблему, яка стоїть перед більшістю українських менеджерів - як передбачити зміни ситуації у галузі через рік, через декілька років. Для відповіді на це питання необхідне достатньо детальне вивчення конкурентного становища в галузі та конкурентних позицій залізничного транспорту на транспортному ринку, на якому він функціонує. Все це в повному обсязі вирішується в ході стратегічного управління та планування.

$$
\text { Сучасний }
$$

характеризується

управлінських рішень

нестабільного, навіть

зовнішнього середовища.

діяльність підприємств в умовах конкуренції все більш залежить від стратегічних дій, які будуть обрані керівництвом.

В вересні 2017 року керівництвом залізничного транспорту України представлено розроблену стратегію розвитку галузі. Слід зазначити, що дана стратегія в основі має тактичні орієнтири, а не стратегічні, що заперечує основні принципи стратегічного управління.

$\begin{array}{ccr}\text { Тому } & \text { сьогодні } & \text { залізничним } \\ \text { підприємствам } & \text { України } & \text { необхідно }\end{array}$ сформувати таку стратегію розвитку, яка б дозволила підтримувати стійкі конкурентні переваги у довгостроковому періоді. Тобто стратегія повинна мати стратегічну спрямованість, а не тактичну. Для розробки такої стратегії необхідний великий обсяг інформації, що можна отримати 3 різних джерел і при самих різноманітних процесах, як у зовнішньому оточенні організації, так і y внутрішньоорганізаційних системах. У зв'язку 3 цим для сучасного менеджера необхідний певний інструментарій для отримання та аналізу інформації, що надходить. Класифікація методів стратегічного менеджменту є необхідним інструментом при виборі способу обробки інформації з метою прийняття адекватних оперативних і стратегічних рішень.

Висновок. Таким чином, для покращення роботи залізничного транспорту України необхідно сформувати таку стратегію розвитку, яка б дозволила підтримувати стійкі конкурентні переваги у довгостроковому періоді, а не лише вирішувала сьогоденні проблеми, при цьому стратегічне управління повинно базуватися на таких передумовах: чітке визначення того, що організація хоче досягти в майбутньому; усвідомлення, що основні проблеми криються у зовнішньому середовищі; вміння своєчасно розпізнавати проблеми та володіти механізмом їх вирішення або зменшення негативного впливу; прийняття управлінських рішень 3 урахуванням відповідності між можливостями, які перебувають поза організацією, та іiі сильними сторонами; налаштування поточного управління на конкретизацію стратегічного управління.

\section{СПИСОК ВИКОРИСТАНИХ ДЖЕРЕЛ}

1. Аванесова Н. Е. Стратегічне управління підприємством : теоретикометодичні засади : монографія / Н. Е. Аванесова, О. В. Марченко - Харків : Щедра садиба плюс, 2015. - 195 с.

2. Балабанова Л. В. Стратегічний менеджмент управління комерційною діяльністю підприємств : монографія / Л. В. Балабанова, А. С. Панчук .- Донецький нац. ун-т економіки і торгівлі ім. М. I. Туган- Барановського. - Донецьк : ДонНУЕТ, 2011. - 181 c.

3. Боярко I. M. Стратегічне фінансове управління підприємством :

Вісник економіки транспорту і промисловості № 59, 2017 
монографія / [І. М. Боярко та ін.]. - Суми : Університетська книга, 2014. - 175 с.

4. Василенко Д. Ю. Методика оценки конкурентоспособности отечественных предприятий / Д. Ю. Василенко // Управління розвитком. - X : ВД «ІНЖЕК», 2012. - № 3. - С. 69-71.

5. Виханский О. С. Стратегическое управление / О. С. Виханский. - 2-е изд., перераб. и доп. - Москва : Гардарики, 2002. $-296 \mathrm{c}$.

6. Воронкова А. Э. Стратегическое управление конкурентоспособным потенциалом предприятия : диагностика и организация / А. Э. Воронкова. - Луганск : ЛНУ, 2000. $-310 \mathrm{c}$.

7. Герасимчук В. Г. Стратегічне управління підприємством. Графічне моделювання / В. Г. Герасимчук. - Київ : КНЕУ, 2016. - $360 \mathrm{c}$.
8.

Менеджмент конкурентоспроможності підприємства: стратегічний підхід та системні рішення : монографія / [О. В. Кендюхов та ін.] ; за заг. ред. О. В. Кендюхова - Донец. нац. техн. ун-т, Каф. стратег. упр. екон. розвитком. - Донецьк : Схід. вид. дім, 2014. $-201 \mathrm{c}$.

9. Стадник В. В. Стратегічне управління інноваційним розвитком підприємства / В. В. Стадник, М. А. Йохна. - Хмельницький : ХНУ, 2011. $327 \mathrm{c}$.

10. Shuki D. The Balanced Scorecard versus quality award models as strategic frameworks / D. Shuki // Total Quality Management \& Business Excellence. Abingdon : Taylor \& Francis, 2008. - Vol. 19. - Issue 6. - P. 583-593.

УДК:656.071(477)

\title{
ТЕОРІЇ УПРАВЛІННЯ РОЗВИТКОМ ЗАЛІЗНИЧНОГО ТРАНСПОРТУ
}

\author{
Островерх Г.С., аспірант (УкрДУЗТ)
}

У статті розглянуто наукові погляди вітчизняних та закордонних вчених щзодо проблеми управління розвитком підприємств залізничного транспорту. Також виділено декілька основних груп, в межах яких застосовуються заходи, які характеризуються схожість механізмів та інструментів реалізації для поліпшення та удосконалення роботи підприємств залізничного транспорту. Аналіз наукових здобутків у сфері управління розвитком підприємств залізничного транспорту, дозволив обтрунтувати необхідність впровадження комплексного механізму управління розвитком на підприємствах залізничного транспорту. Даний механізм повинен мати декілька рівнів реалізачії та включати сукупність елементів. Визначено, щуо в основі реалізації даного комплексного механізму управлінням розвитку повинні знаходитися стандарти державної транспортної політики, галузеві програми $i$ стратегіi розвитку, а також Міністерство інфраструктури Украӥни та самі підприємства залізничного транспорту.

Ключові слова: залізничний транспорт, управління, розвиток, стратегія розвитку, Міністерство інфраструктури України, галузеві програми. 